\title{
ANALISIS PENGARUH FAKTOR INTERNAL DAN EKSTERNAL TERHADAP KINERJA USAHA MIKRO KECIL DAN MENENGAH (UMKM)
}

\author{
Tutik Siswanti \\ Program Studi Akuntansi - Fakultas Ekonomi \\ Universitas Dirgantara Marsekal Suryadarma \\ tutysis12@gmail.com
}

\begin{abstract}
ABSTRAK
Penelitian ini bertujuan untuk mengetahui pengaruh faktor internal dan faktor ekternal terhadap kinerja UMKM. Obyek penelitian ini adalah UMKM yang berlokasi di 3 (tiga) wilayah Kecamatan Bekasi Timur, Bekasi, Jawa Barat, yaitu meliputi ; UMKM di Kelurahan Duren Jaya, Kelurahan Aren Jaya, dan Kelurahan Bekasi Jaya. Jumlah sampel dalam penelitian ini sebanyak 300 responden, yang diwakli 100 responden untuk setiap kelurahan.

Metode pengumpulan data dilakukan dengan kuesioner tertutup. Metode Penelitian yang digunakan dalam penelitian ini adalah diskriptif kuantitatif, dengan alat analisis statistis regresi liner berganda, sedang uji hipotesis dilakukan dengan hipotesis parsial dan hipotesis simultas.

Hasil penelitian ini menunjukkan bahwa faktor internal dan faktor ekternal memiliki hubungan positif dan searah, yang ditunjukkan dengan nilai koefisien b1 sebesar 0, 673, dan b2 sebesar 0,308. Sedangkan hasil uji hipotesis secara parasial variabel bebas tersebut berpengaruh terhadap kinerja UMKM yang ditunjukkan dengan nilai $t_{\text {hitung }}>t_{\text {tabel. }}$. Hasil uji hipotesis secara simultan juga menunjukkan bahwa secara bersama-sama faktor internal dan faktor eksternal berpengaruh terhadap kinerja UMKM, dimana nilai $F_{\text {hitung }}>F_{\text {tabe }} l$, dan nilai koefisien determinasi sebesar $46,4 \%$.
\end{abstract}

Kata Kunci : Faktor Internal, Faktor Ekternal, Kinerja, UMKM

\section{PENDAHULUAN}

\subsection{Latar Belakang Masalah}

Pertumbuhan Usaha Mikro Kecil dan Menengah (UMKM) di Indonesia sangat maju, dan saat ini menjadi salah satu prioritas dalam pembangunan ekonomi nasional. Hal ini selain karena bisnis usaha kecil adalah tulang punggung sistem ekonomi rakyat, dan memiliki efek menyerap tenaga kerja yang dapat mengurangi masalah pengangguran, serta kesenjangan ekonomi antara kelompok, pendapatan, dan pengentasan kemiskinan. Lebih dari itu, pertumbuhan UMKM mampu memperluas basis ekonomi dan dapat berkontribusi secara signifikan dalam mempercepat perubahan struktural, yaitu meningkatkan ekonomi regional dan ketahanan ekonomi nasional. Meningkatnya peran dan aktivitas bisnis sektor ini semakin terlihat, terutama sejak era krisis ekonomi dan keuangan tahun 1998. Di tengah lambatnya proses restrukturisasi sektor korporasi dan BUMN, sektor ini telah menunjukkan kemajuan yang semakin meningkat dan bahkan mampu mendukung pertumbuhan ekonomi nasional. Keberhasilan Usaha Mikro Kecil dan Menengah (usaha kecil menengah) memiliki pengaruh langsung terhadap perkembangan ekonomi, baik di negara maju maupun negara berkembang. Usaha Mikro Kecil dan Menengah memiliki kemampuan untuk menciptakan lapangan kerja dengan biaya minimum. Perusahaan kecil dan menengah 
adalah pelopor dalam dunia inovasi dan memiliki fleksibilitas tinggi yang memungkinkan bisnis untuk memenuhi kebutuhan pelanggan.

Peran yang dilakukan oleh UMKM diharapkan tetap berkelanjutan, dengan bantuan dan peran pemerintah serta pihakpihak terkait untuk meningkatkan kinerja bisnisnya. Pada dasarnya kinerja sektor Usaha Mikro Kecil dan Menengah (UMKM) dipengaruhi oleh dua faktor utama, yaitu faktor eksternal dan faktor internal. Faktor internal merupakan faktor yang bersumber dari dalam usaha bisnis tersebut dan biasanya dapat dikendalikan. Sedangkan faktor eksternal merupakan faktor yang bersumber dari luar kegiatan usaha yang sulit untuk di kendalikan.

UMKM di kota Bekasi dari tahun ke tahun mengalami pertumbuhan yang cukup signifikan. Jumlah UMKM binaan Pemkot Bekasi tahun 2017 sebanyak 2.667, sepanjang 2018, jumlah UMKM di Kota Bekasi mengalami peningkatan menjadi 2.886, sehingga UMKM binaan Pemertintah Kota Bekasi mengalami kenaikan sebanyak 219 UMKM. Para pelaku UMKM ini tersebar di 12 (dua belas) kecamatan, dimana UMKM tersebut telah berhasil menyerap tenaga kerja sebanyak 410.000 orang. Kegiatan pelaku usaha meliputi berbagai bidang, mulai dagang, jasa, kontruksi, dan lainnya. Pada penelitian ini akan di fokuskan obyek penelitian di wilayah Kecamatan
Bekasi Timur, dan populasi UMKM pada 3 (tiga) Keluarahan, yaitu Duren Jaya, Aren Jaya, dan Bekasi Jaya.

Penelitian yang berkaitan dengan mengukur pengaruh faktor internal dan eksternal terhadap kinerja UMKM di wilayah Kecamatan Bekasi Timur ini perlu dilakukan, mengingat UMKM di wilayah Kecamatan Bekasi Timur mampu menyerap tenaga kerja, sehingga mengurangi pengangguran dan juga mempu meningkatkan pendapatan masyarakat. Oleh karena itu mngetahui faktor-faktor yang dapat menghambat kinerja UMKM menjadi salah satu bagian yang perlu mendapatkan perhatian, agar UMKM dapat melakukan antisipasi dan meminimalisasi faktor-faktor tersebut, sehingga UMKM dapat meningkatkan kinerjanya.

\subsection{Masalah Penelitian}

Berdasarkan latar belakang masalah dan penelitian terdahulu, maka masalah penelitian ini adalah sebagai berikut :
a. Bagaimana pengaruh Faktor Internal terhadap Kinerja Usaha Mikro Kecil dan Menengah di Kecamatan Bekasi Timur
b. Bagaimana pengaruh Faktor Eksternal terhadap Kinerja Usaha Mikro Kecil dan Menengah di Kecamatan Bekasi Timur
c. Bagaimana pengaruh Faktor Internal dan Faktor Eksternal terhadap Kinerja Usaha Mikro Kecil dan Menengah di Kecamatan Bekasi Timur 


\subsection{Tujuan Khusus Penelitian}

Penelitian ini di lakukan memiliki tujuan, dimana tujuan penelitian ini sejalan dengan permasalahan yang akan diteliti. Adpun tujuan dari penelitian ini adalah untuk mengetahui :

a. Pengaruh secara parsial atau secara individu Faktor Internal dan Faktor Eksternal terhadap Kinerja Usaha Mikro Kecil dan Menengah di Kecamatan Bekasi Timur

b. Pengaruh secara simultan atau secara bersama-sama Faktor Internal dan Faktor Eksternal terhadap Kinerja Usaha Mikro Kecil dan Menengah di Kecamatan Bekasi Timur

\subsection{Manfaat Penelitian}

UMKM merupakan kegiatan usaha yang sangat besar peranannya dalam pertumbuhan ekonomi, serta pengentasan kemiskinan, maupun dalam mengurangi jumlah pengangguran, Namun demikian pertumbuhan UMKM pada saat ini masih sangat rendah, hal ini karena para pelaku UMKM tidak memahami dan cenderung tidak peduli terkait perkembangan usahanya. Oleh karena itu dengan adanya penelitian ini maka dapat dmanfaatkan oleh :

a. UMKM, diharapakan pada pelaku UMKM dapat mengidentifikasi faktorfaktor apa saja yang dominan mmpengaruhi kinerja usahanya. b. Pemerintah dan swasta, tu penelitian ini juga dapat dimanfaatkan sebagai bahan kajian serta pertimbangan para pengambil kebijakan maupun regulator, baik pemerintah maupun swasta dalam memberikan pendampingan, bimbingan, serta permodalan dalam rangka membantu pertumbuhan UMKM.

\section{TINJAUAN PUSTAKA}

\subsection{Usaha Mikro Kecil Dan menengah (UMKM)}

\section{Pengertian UMKM}

Usaha Mikro Kecil dan Menengah (UMKM) memiliki definisi yang berbeda pada setiap literatur menurut beberapa instansi atau lembaga bahkan undangundang.Sesuai dengan Undang-Undang nomor 20 tahun 2008 tentang Usaha Mikro Kecil dan Menengah.

UMKM didefinisikan sebagai berikut:

a. Usaha mikro adalah usaha produktif milik orang perorangan dan/atau badan usaha perorangan yang memenuhi kriteria Usaha Mikro sebagaimana diatur dalam UndangUndang ini.

b. Usaha Kecil adalah usaha ekonomi produktif yang berdiri sendiri, yang dilakukan oleh orang perorangan atau badan usaha yang bukan merupakan anak perusahaan atau bukan cabang perusahaan yang dimiliki, dikuasai, atau menjadi bagian baik langsung maupun tidak langsung dari Usaha Menengah atau 
Usaha Besar yang memenuhi kriteria Usaha Kecil sebagaimana dimaksud dalam Undang-Undang ini.

c. Usaha Menengah adalah usaha ekonomi produktif yang berdiri sendiri, yang dilakukan oleh orang perorangan atau badan usaha yang bukan merupakan anak perusahaan atau cabang perusahaan yang dimiliki, dikuasai, ataupun menjadi bagian baik langsung maupun tidak langsung dengan Usaha Kecil atau Usaha Besar dengan jumlah kekayaan bersih atau hasil penjualan tahunan sebagaimana diatur dalam Undang-Undang ini.

Berdasarkan kekayaan dan hasil penjualan, menurut Undang-Undang Nomor 20 tahun 2008 pasal 6, kriteria usaha mikro yaitu:

a. Memiliki kekayaan bersih paling banyak Rp 50.000.000,00 (lima puluh juta rupiah) tidak termasuk tanah dan bangunan tempat usaha; atau

b. Memiliki hasil penjualan tahunan paling banyak Rp 300.000.000,00 (tiga ratus juta rupiah

\section{Klasifikasi UMKM}

Klasifikasi Usaha Mikro Kecil dan Menengah (Ade Resalawati, 2011) :

a. Livelhood Activities, merupakan UMKM yang digunakan sebagai kesempatan kerja untuk mencari nafkah, yang labih umum biasa disebut sektor informal. Contohnya pedagang kaki lima. b. Micro Enterprise, merupakan UMKM yang memiliki sifat pengrajin tetapi belum memiliki sifat kewirausahaan.

c. Small Dynamic Enterprise, merupakan UMKM yang telah memiliki jiwa kewirausahaan dan mampu menerima pekerjaan subkontrak dan ekspor.

d. Fast Moving Enterprise, merupakan UMKM yang telah memiliki jiwa kewirausahaan dan akan melakukan transformasi menjadi Usaha Besar (UB).

\section{Karakteristik UMKM}

Pandji Anoraga (2010) menjelaskan bahwa secara umum, sektor usaha kecil memiliki karakteristik sebagai berikut:

a. Sistem pembukuan yang relatif administrasi pembukuan sederhana dan cenderung tidak mengikuti kaidah admistrasi pembukuan standar. Kadangkala pembukuan tidak di up to date sehingga sulit untuk menilai kerja usahanya.

b. Margin usaha yang cenderung tipis mengingat persaingan yang sangat tinggi.

c. Modal terbatas

d. Pengalaman menejerial dalam mengelola perusahaan masih sangat terbatas.

e. Skala ekonomi yang terlalu kecil sehingga sulit mengharapkan untuk mampu menekan biaya mencapai titik efisieni jangka panjang.

f. Kemampuan pemasaran dan negosiasi serta diversifikasi pasar sangat terbatas. 
g. Kemampuan untuk sumber dana dari pasar modal terendah, mengingat keterbatasan salam sistem administrasinya.

\section{Kekuatan dan Kelemahan UMKM}

Kelemahan, yang sering juga menjadi faktor penghambat dan permasalahan dari Usaha Mikro terdiri dari 2 faktor (Samir, A \& Larso, D. 2011) :

a. Faktor Internal ;

Merupakan masalah klasik dari UMKM yaitu diantaranya:

1) Masih terbatasnya kemampuan sumber daya manusia.

2) Kendala pemasaran produk sebagian besar pengusaha Industri Kecil lebih memperioritaskan pada aspek produksi sedangkan fungsi-fungsi pemasaran kurang mampu dalam mengakseskannya, khususnya dalam informasi pasar dan jaringan pasar, sehingga sebagian besar hanya berfungsi sebagai tukang saja.

3) Kecenderungan konsumen yang belum mempercayai mutu produk Industri Kecil.

4) Kendala permodalan usaha sebagian besar Industri Kecil memanfaatkan modal sendiri dalam jumlah yang relatif kecil

b. Faktor eksternal ;

Merupakan masalah yang muncul dari luar kegiatan usaha, kondisi ekonomi, pihak pengembang dan pembina UMKM. Kebijakan pemerintah, undang-undang, regulasi, dan juga beberapa solusi yang diberikan tidak tepat sasaran atau tidak adanya monitoring. Faktor eksternal, yang meliputi ; Pemerintah dan swasta (perbankan, BUMN), LSM dan lembaga pendamping lainnya sudah siap dengan pemberian kredit, tetapi UMKM mana yang diberi, karena berbagai ketentuan yang harus dipenuhi oleh UMKM.

\subsection{Faktor Internal UMKM}

Pearce II dan Robinson (2013) mendefinisikan lingkungan eksternal merupakan faktor-faktor diluar kendali yang mempengaruhi pilihan perusahaan terkait arah dan tindakan, yang pada akhirnya juga mempengaruhi struktur organisasi dan proses internalnya. David (2010), menjelaskan bahwa lingkungan eksternal perusahaan (external business environment) adalah berbagai faktor yang berada diluar organisasi yang harus diperhitungkan oleh organisasi perusahaan dalam pengambilan keputusan.

Penelitian yang dilakukan oleh Maupa (2014) menunjukkan:

a. Karakteristik manajer / pemilik individu, karakteristik perusahaan, lingkungan eksternal bisnis, dan dampak kebijakan ekonomi dan sosial memiliki pengaruh langsung, positif, dan signifikan terhadap strategi bisnis dan pertumbuhan bisnis; 
b. Karakteristik perusahaan, dan dampak kebijakan sosial dan ekonomi memiliki pengaruh langsung negatif pada strategi bisnis; dan

c. Strategi bisnis memiliki pengaruh langsung, positif, dan signifikan terhadap pertumbuhan perusahaan.

\subsection{Faktor Eksternal UMKM}

Lingkungan eksternal adalah suatu pengaruh lingkungan yang berasal dari luar perusahaan baik yang sangat dekat dengan perusahaan maupun yang agak jauh, dan secara langsung atau tidak langsung akan mempengaruhi kegiatan perusahaan secara keseluruhan.

Analisis lingkungan internal perusahaan merupakan suatu proses perencanaan strategi yang mengkaji bidang pemasaran, distribusi, penelitian dan pengembangan, produksi dan operasi, sumber daya dan karyawan perusahaan, serta faktor keuangan dan akuntansi untuk menganalisa kekuatan dan kelemahan masing-masing divisi tersebut, sehingga perusahaan dapat memanfaatkan peluang dengan cara yang paling efektif dan dapat menangani ancaman.

David (2010), mengatakan faktorfaktor eksternal utama (external force) dalam melakukan analisis lingkungan eksternal dibagi menjadi lima kategori : a). Kekuatan ekonomi, b). Kekuatan sosial, c). Kekuatan politik, d). Kekuatan teknologi dan, e). Kekuatan kompetitif.
Penelitian ini akan mengukur pengaruh faktor-faktor internal dan eksternal terhadap kinerja Usaha Mikro Kecil dan Menengah (UMKM).

Faktor internal diukur dengan aspek Sumber Daya Manusia (pemilik, manajer, dan karyawan); aspek keuangan, aspek teknis produksi, dan aspek pemasaran. Faktor eksternal diukur dengan kebijakan pemerintah, aspek sosial budaya dan ekonomi, dan peran lembaga terkait seperti Pemerintah, Perguruan Tinggi, Swasta, dan Organisasi non-pemerintah. (Maupa, 2010 )

\subsection{Kinerja}

\section{Pengertian Kinerja}

Pengertian Kinerja Menurut Jeaning dan Beaver (2012) kinerja perusahaan secara umum merupakan tolak ukur keberhasilan dan perkembangan suatu perusahaan kecil (usaha kecil). Pengukuran yang dilakukan perusahaan terhadap kinerja yaitu tentang seberapa besar keuntungan yang diperoleh, besar investasi, dan pertumbuhan jumlah tenaga kerja serta perkembangan perusahaan secara umum.

$$
\text { Menurut Prawirosentono }
$$

kinerja yaitu suatu pencapaian kerja yang dilakukan oleh orang atau badan usaha atau organisasi, sesuai dengan kewajiban dan tanggung jawab masing-masing dalam upaya mencapai visi dan tujuan usaha, atau organisasi dan tidak melupakan kaidah 
hukum yang berlaku sesuai dengan moral dan etika.

Strategi bisnis para manager sangat mempengaruhi imbalan atau bahkan resiko yang diterima perusahaan karena investasi. Menurut Mulyadi yang dikutip Husein (2016), untuk mengukur kinerja dapat dilihat dari pendapatan perusahaan, sedangkan besarnya pendapatan bisa lihat dari pusat laba. Pusat laba merupakan pusat pertanggung jawaban manager dalam mengendalikan pendapatan, dan untuk mengukur pusat laba tersebut adalah dengan melihat produktivitas perusahaan.

\section{Kinerja UMKM}

Aribawa (2016) menyatakan bahwa kinerja UMKM merupakan hasil kerja yang di capai oleh seorang individu dan dapat diselesaikan dengan tugas individu tersebut didalam perusahaan dan pada suatu periode tertentu, dan akan dihubungkan dengan ukuran nilai atau standard dari perusahaan yang individu bekerja. Kinerja disini sendiri adalah capaian yang akan diperoleh seseorang maupun perusahaan yang akan mecapai dalam suatu tujuan tertentu. Menurut Aribawa (2016) kinerja merupakan keberhasilan suatu organisasi yang mewujudkan sasaran yang strategic dan telah ditetapkan sebelumnya dengan perilaku yang akan diharapkan oleh suatu organisasi tersebut.

\section{Indikator Kinerja UMKM}

UMKM yang memiliki kinerja yang dihasilkan baik maka akan semakin kokoh untuk menjadi tulang punggung pada perekonomian dan semakin memiliki peran penting dalam perekonomian Nasional. Menurut Rapih, (2015) berikut ini adalah indikator dari Kinerja UMKM :

a. Pertumbuhan penjualan, artinya jumlan volume penjualan akan semakin meningkat, sehingga dapat meningkatkan pendapatan yang menjadi sumber penerimaan utama perusahaan. Dengan meningkatnya jumlah pendapatan dengan asumsi biaya konstan, hal ini berarti aset perusahaan bertambah.

b. Pertumbuhan pelanggan, dimana pelanggan merupakan pihak yang menentukan jumlah produk yang terjual, dengan meningkatnya jumlah pelanggan menunjukakan bertambahnya segmen pasar yang dapat menambah jumlah penjualan.

c. Pertumbuhan keuntungan, laba nerupakan sumber penambahan modal perusahaan, dengan meningkatnya laba menunjukan perusahaan mengelola keuanghan dengan baik, efektif dalam menggunakan dana dan efisien dalam pengelolaan dananya.

\section{Faktor Yang Mempengaruhi Kinerja UMKM}

Faktor internal adalah faktor dari dalam usaha tersebut berada, berikut yang 
termasuk faktor internal yang menghambat UMKM (Aribawa, 2016):

a. Modal ; Sebanyak 60\%-70\% UMKM di Indonesia belum mendapatkan pembiayaan perbankan. Hal ini dikarenakan belum banyak perbankan yang mampu menjangkau hingga ke daerah pelosok dan terpencil, kendala dalam menejemen keuangan juga menjadi pemicu tidak adanya modal dari perbankan karena menejemen keuangan kebanyakan UMKM masih sangat tradisional sehingga pengelola atau pengusaha susah membedakan uang operasional perusahaan dan uang pribadi atau rumah tangga.

b. Sumber daya manusia ; Kurangnya pengetahuan tentang teknologi baru yang dapat mempercepat produksi, serta minimnya pengetahuan untuk tetap bisa mengontrol kualitas produk yang ada.

c. Hukum ; Umumnya pengusaha UMKM masih belum berbadan hukum, karena sifatnya usaha perorangan atau usaha keluarga.

d. Akuntabilitas ; Pada umumnya UMKM yang ada di Indonesia belum mampu dalam hal menejemen perusahaan yang baik dan belum cakap dalam hal administrasi.

\subsection{Kerangka Pemikiran}

Penelitian ini akan mengkaji dan menganalisis hubungan dan pengaruh antara faktor internal dan faktor ekternal terhadap kinerja UMKM baik secara parsial maupun secara simultan.

Adapun faktor internal akan diukur menggunakan beberapa aspek yaitu : aspek SDM, Aspek Keuangan, Aspek teknik Produksi, Aspek pemasaran. Sedangkan Faktor Eksternal akan diukur berdasarkan aspek pemerintah, kondisi ekonomi, dan lembaga terkait. Variabel Kinerja UMKM akan diukur dari aspek pertumbuhan penjualan, pertumbuhan aset, pertumbuhan SDM, dan Petumbuhan laba. Secara konseptual berdasarkan literaris bahwa apabila perusahaan memiliki kekutan dari sisi internal dan mampu memnfaatkan peluang dari faktor eksternal, maka perusahaan akan mampu meningkatkan kinerjanya. Dimana dalam memaksimalkan kekuatan internal perusahaan hasru memperhatiakan berbagai aspek antara lain ; aspek SDM, Aspek Keuangan, Aspek teknik Produksi, Aspek pemasaran. Demikain halnya dengan kemampuan perusahaan dalam memanfaatkan berbagai ancaman yang berasal dari luar usaha, antara lain ; kebijakan dan fasilitas pemerintah, kondisi ekonomi, dan lembaga terkait LSM, swasta dan lainlain, maka perusahaan akan mampu menyesuaian diri dengan perubahanperubahan sehingga menjadi perusahaan yang mampu meningkatkan kinerjanya dan akhirnya menjadi perusahaan yang tumbuh dan kuat. . 
Adapun kerangka pemikiran dalam penelitian ini sebagai berikut :

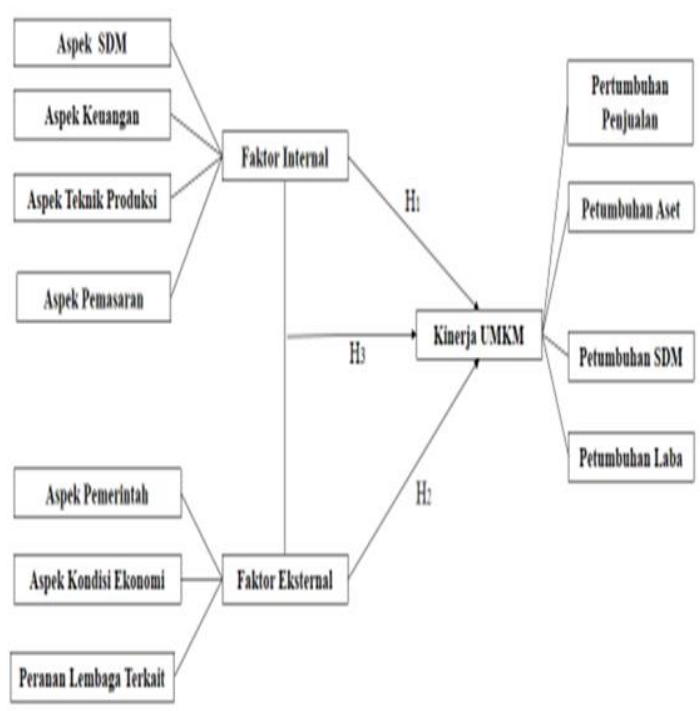

\section{Gambar 1. Kerangka Pemikiran}

\subsection{Hipotesisi Penelitian}

Berdasarkan kerangka pemikiran dan konseptual teori tersebut, maka hipoteisis dalam penelitian ini adalah sebagai berikut :

H1 : Diduga Faktor Internal memiliki hubungan dan pengaruh terhadap Kinerja UMKM

H2 : Diduga Faktor Eksternal memiliki hubungan dan berpengaruh terhadap Kinerja UMKM

H3 : Diduga Faktor Internal dan Eksternal dan memiliki hubungan dan berpengaruh terhadap Kinerja UMKM

\section{METODOLOGI PENELITIAN}

\subsection{Obyek dan Waktu Penelitian}

Obyek yang menjadi sumber data dalam penelitian ini adalah pelaku UMKM yang menjalankan kegiatan usaha di 3 (tiga) lokasi Wilayah Bekasi Timur, yaitu yaitu Kelurahan Duren Jaya, Kelurahan Aren Jaya, dan Kelurahan Bekasi Jaya.

Waktu penelitian dilakukan selama 1 (satu tahun), yaitu terhitung mulai Maret 2019 s/d Maret 2020.

\subsection{Populasi dan Sampel Penelitian}

Populasi dalam penelitian ini adalah seluruh UMKM bidang usaha kuliner dan perdagangan, yang menjalankan usaha di 3 (tiga) lokasi, yaitu Wilayah Bekasi Timur, yaitu yaitu Kelurahan Duren Jaya, Kelurahan Aren Jaya, dan Kelurahan Bekasi Jaya. Adapun karakteristik responden yang menjadi sumber data dalam penelitian ini adalah :

a. UMKM bidang kuliner dan perdagangan

b. Lokasi usaha di Kelurahan Duren Jaya, Kelurahan Aren Jaya, dan Kelurahan Bekasi Jaya.

c. Telah menjalankan usaha minimal 3 tahun

d. Memiliki ijin usaha dari pejabat setempat (minimal RW)

e. Pernah menggunakan fasilitas pinjaman bank atau KUR

Berdasarkan karakteristik tersebut, maka jumlah populasi pada masing-masing wilayah sebanyak 100 UMKM.

Sampel dalam penelitian ini dilakukan dengan sampel jenuh, dimana seluruh populasi digunakan sebagai sampel penelitian. Dengan demikian jumlah sampel 
dalam penelitian ini sebanyk 300 UMKM, dengan proporsi penambilan sampel masingmasing lokasi adalah 100 UMKM

\subsection{Jenis dan Sumber Data}

Jenis data dalam penelitian ini adalah data kualitatif, yaitu data yang berseunber dari jawaban reponden. Namun demikian untuk keperluan pengolahan data dengan memnggunakan analisis statistik maka data kualitatif tersebut selanjutnya dikuantitatifkan dengan menggunakan skala lingker. Hal ini karena jenis penelitian ini adalah penelitian kuantitatif dimana data dianalisis dengan menggunakan statistik, sehingga jenis data harus kuantitatif.

Sumber data dalam penelitian ini merupakan data primer, yaitu data yang dikumpulkan langsung dari jawaban responden, sehingga data tersebut masih data asli yang belum melalui proses pengolahan data.

\subsection{Metode Pengumpulan Data}

Pengumpulan data dalam penelitian ini dilakukan dengan menyebar kuesioner kepada responden. Adapun sifat kuesioner dalam penelitian ini adalah kuesioner tertutup, dimana reponden menjawab dengan cara memilih sesuai dengan jawaban yang telah disediakan.

\subsection{Metode Analisis Data}

Metodologi yang digunakan dalam penelitian ini adalah diskriptif kuantitatif dengan pendekatan regresi liner berganda. Sedangkan metode analisis data dengan analisis statistik, dimana pengolahan data menggunakan software SPSS version 22

\section{ANALISIS DAN PEMBAHASAN}

\subsection{Uji Instrumen Penelitian}

a. Uji Validitas

Uji validitas dalam penelitian ini diukur dengan membandingkan antara hasil ouput r-hitung dengan r-tabel. Kriteria hasil pengujian adalah, jika hasil r-hitung lebih besar dari r-tabel, maka dapat disimpulkan bahwa seluruh instrument variabel valid. Dengan nilai $\mathrm{n}$ sebanyak 30 , dan tingkat siginifikansi sebesar $5 \%$ nilai r-tabel 0,3610 .

Hasil Uji Validitas untuk Insrumen penelitian dari 3 variabel dalam penelitian ini sebagai berikut :

Tabel 1. Uji Validitas Instrumen Penelitian

\begin{tabular}{|c|c|c|c|c|}
\hline Instrumen & $\begin{array}{c}\text { Faktor } \\
\text { Internal }\end{array}$ & $\begin{array}{c}\text { Faktor } \\
\text { Ekternal }\end{array}$ & $\begin{array}{c}\text { Kinerja } \\
\text { UMKM }\end{array}$ & Simpulan \\
\hline P1 & 0,487 & 0,460 & 0,659 & Valid \\
\hline P2 & 0,415 & 0,435 & 0,419 & Valid \\
\hline P3 & 0,466 & 0,411 & 0,509 & Valid \\
\hline P4 & 0,410 & 0,455 & 0,462 & Valid \\
\hline P5 & 0,582 & 0,655 & 0,593 & Valid \\
\hline P6 & 0,514 & 0,427 & 0,464 & Valid \\
\hline P7 & 0,460 & 0,439 & 0,457 & Valid \\
\hline P8 & 0.582 & 0,432 & 0,410 & Valid \\
\hline P9 & 0,451 & 0,462 & 0,402 & Valid \\
\hline P10 & 0,533 & 0,483 & 0,539 & Valid \\
\hline & \multicolumn{5}{|c|}{ Sumber : Pengolahan Data, 2019 } \\
\hline
\end{tabular}




\section{b. Uji reliabilitas}

Uji Reliabilitas dalam penelitian ini menggunakan Cronbach's Alpha. Hasil Uji Reliabilitas dari instrument penelitian untuk 3 varaiabel dalam penelitian ini sebagai berikut:

Tabel 2. Uji reliabilitas Instrumen Penelitian

\begin{tabular}{|l|c|c|}
\hline \multicolumn{1}{|c|}{ Instrumen } & $\begin{array}{c}\text { Nilai } \\
\text { Cronbach's } \\
\text { Alpha }\end{array}$ & Simpulan \\
\hline Faktor Internal & 0,530 & Reliabel \\
\hline Faktor Eksternal & 0,418 & Reliabel \\
\hline Kinerja UMKM & 0,512 & Reliabel \\
\hline \multicolumn{3}{|c|}{ Sumber : Pengolahan Data, 2019 }
\end{tabular}

Berdasarkan tabel diatas, menunjukkan bahwa nilai cronbach's alpha dari seluruh instrument penelitian lebih besar dari $\mathrm{r}$ tabel, sehingga dapat disimpulkan bahwa seluruh item instrument dalam penelitian ini reliabel.

\subsection{Hasil Analisis Regresi Berganda}

Hasil output persamaan tersaji dalam tabel dibawah ini :

Tabel 3. Regresi Linier Berganda

\begin{tabular}{|c|c|c|c|c|c|c|}
\hline \multirow{2}{*}{\multicolumn{2}{|c|}{ Model }} & \multicolumn{2}{|c|}{\begin{tabular}{|l|} 
Unstandardized \\
Coefficients \\
\end{tabular}} & \multirow{2}{*}{$\begin{array}{c}\begin{array}{r}\text { Standardized } \\
\text { Coefficients }\end{array} \\
\text { Beta }\end{array}$} & \multirow[t]{2}{*}{$\mathrm{t}$} & \multirow[t]{2}{*}{ Sig. } \\
\hline & & B & $\begin{array}{l}\text { Std. } \\
\text { Error }\end{array}$ & & & \\
\hline & (Constant) & ,460 & 4,788 & & 3,229 & ,002 \\
\hline & $\begin{array}{l}\text { FAKTOR } \\
\text { INTERNAL }\end{array}$ & 673, & ,082 & ,514 & 5,833 & ,000 \\
\hline & $\begin{array}{l}\text { FAKTOR } \\
\text { EKSTERNAL }\end{array}$ & ,308 & ,097 & ,398 & 3,116 & ,067 \\
\hline
\end{tabular}

Berdasarkan tabel diatas persamaan regresi berganda sebagai berikut :

$$
Y=0,460+0,673 X_{1}+0,308 X_{2}
$$

Dari persamaan regresi tersebut dapat dijelaskan sebagai berikut : a. Konstanta sebesar 0,460 hal ini berarti bahwa, jika Faktor Internal $\left(\mathrm{X}_{1}\right)$ dan Faktor Eksternal $\left(\mathrm{X}_{2}\right)$ nilainya 0 , maka nilai variabel terikat (Beta) Kinerja UMKM (Y) sebesar 0,460.

b. Koefisien regresi Faktor Internal $\left(\mathrm{X}_{1}\right)$ sebesar 0,676. Koefisien variabel bebas Faktor Internal $\left(\mathrm{X}_{1}\right)$ bernilai positif, hal ini menunjukkan, bahwa hubungan antara variabel bebas $\left(\mathrm{X}_{1}\right)$ dengan variabel terikat $(\mathrm{Y})$ positif, searah atau berbanding lurus, dimana jika Variabel Faktor Internal (X1) meningkat, maka Kinerja UMKM (Y) juga akan mengalami peningkatan, dan sebaliknya. Berdasarkan nilai tersebut diatas, maka berarti jika nilai variabel Faktor Internal (X1) naik sebesar satu satuan, maka nilai Kinerja UMKM (Y) akan mengalami kenaikan sebesar 0,673, dan sebaliknya dengan asumsi bahwa variabel bebas yang lain dari model regresi adalah konstan atau tetap.

c. Koefisien regresi Faktor Eksternal $\left(\mathrm{X}_{2}\right)$ sebesar 0,308. Koefisien variabel Faktor Eksternal $\left(\mathrm{X}_{2}\right)$ bernilai positif, hal ini menunjukkan, bahwa hubungan antara variabel bebas $\left(\mathrm{X}_{2}\right)$ dengan variabel terikat (Y) positif, searaha atau berbanding lurus, dimana jika Variabel Faktor Eksternal meningkat sebesar satu satuan, maka Kinerja UMKM akan mengalami peningkatan sebesar 0,308, 
dan sebaliknya, dengan asumsi variabel bebas yang lain konstan atau tetap.

\subsection{Uji Asumsi Klasik}

\section{a. Uji Multikolinearitas}

Hasil uji multikolinearitas, menunjukkan Nilai VIF untuk variabel Faktor Internal dan Faktor Eksternal sebesar $1.002<10$, dan Nilai Tolerance Value kedua variabel masing-masing 0,998 >0,10, maka dapat disimpulkan bahwa kedua variabel bebas tersebut tidak mengandung multikolinearitas.

\section{b. Uji Heterokedastisitas}

Berdasarkan hasil uji heterokedastisitas, menunjukan nilai korelasi kedua variabel untuk vaiabel independen dengan Unstandardized Residual memiliki nilai signifikansi > 0,05, yaitu sebesar 0,540 untuk variabel Faktor Internal dan 0,563, untuk variabel Faktor Eksternal dengan demikian dapat disimpulkan bahwa bahwa tidak terjadi masalah heterokedastisitas pada model regresi dalam penelitian ini.

\subsection{Hasil Hipotesis Penelitian}

Uji Hipotesis Pengaruh Parsial Variabel Faktor Internal terhadap Kinerja UMKM, menunjukkan $t_{\text {hitung }}$ untuk variabel bebas Faktor Internal sebesar 5,833, dan thitung untuk varaibel Faktor Eksternal sebesar 3,116, sedangkan $t_{\text {tabel }}$ sebesar 1,9679 . Dengan demikian nilai $t_{\text {hitung }}>$ nilai $t_{\text {tabel }}$. Sehingga variabel bebas Faktro Internal dan
Faktor Eksternal secara parsial berpengaruh signifikan terhadap Kinerja UMKM.

Hasil output uji hipotesis simultan sebagaib berikut :

Tabel 4. Uji Hipotesisi Simultan

\begin{tabular}{|c|c|c|c|c|c|c|}
\hline \multicolumn{7}{|c|}{ ANOVA $^{a}$} \\
\hline \multicolumn{2}{|c|}{ Model } & $\begin{array}{c}\text { Sum of } \\
\text { Squares }\end{array}$ & df & $\begin{array}{c}\text { Mean } \\
\text { Square }\end{array}$ & $\mathrm{F}$ & Sig. \\
\hline \multirow{3}{*}{1} & Regression & 230,033 & 2 & 115,017 & 17,956 &, $000^{b}$ \\
\hline & Residual & 595,706 & 293 & 6,405 & & \\
\hline & Total & 825,740 & 295 & & & \\
\hline
\end{tabular}

Sumber : Pengolahan Data, 2019

Berdasarkan output diatas, menunjukkan nilai $F_{\text {hitung }}$ sebesar 17,956, sedangkan $\mathrm{F}_{\text {tabel }}$ sebesar 3,16, dengan demikian nilai $\mathrm{F}_{\text {hitung }}>$ nilai $\mathrm{F}_{\text {table. Sehingga }}$ hal ini berarti variabel-variabel bebas Faktor Internal dan Faktor Eksternal secara simultan atau secara serempak berpengaruh signifikan terhadap variabel terikat Kinerja UMKM.

\subsection{Hasil Koefisien Determinasi}

Hasil output pengolahan data koefisien determinasi sebagai berikut :

Tabel 5. Koefisien determinasi

\begin{tabular}{|l|r|r|r|r|}
\hline Model & $\mathrm{R}$ & R Square & $\begin{array}{c}\text { Adjusted R } \\
\text { Square }\end{array}$ & $\begin{array}{c}\text { Std. Error of } \\
\text { the Estimate }\end{array}$ \\
\hline 1 &, $681^{\mathrm{a}}$ &, 464 &, 445 & 1,499 \\
\hline
\end{tabular}

a. Predictors: (Constant), FAKTOR INTERNAL, FAKTOR EKSTERNAL

b. Dependent Variable: KINERJA UMKM

Sumber : Pengolahan Data, 2019

Nilai koefisien determinasi menunjukkan nilai $\mathrm{R}$ square sebesar 0,464 . Hal ini berarti variabel-variabel bebas Faktor 
Internal dan Faktor Eksternal mampu menjelaskan varian variabel terikat Kinerja UMKM sebesar 46,4\%, sedangkan sebesar $53,6 \%$ varian variabel terikat dijelaskan oleh variabel lain yang tidak digunakan sebagai pengukuran dalam persamaan regresi linier berganda pada penelitian ini .

\subsection{Pembahasan}

Hasil penelitian ini menunjukkan bahwa faktor internal memiliki hubungan positif dan searah, serta berpengaruh terhadap kinerja UMKM. Hal ini menjukkan bahwa kinerja UMKM yang diukur dengan pertumbuhan penjualan, pertumbuhan pendapatan,pertumbuhan laba, pertumbuhan modal, peningkatan jumlah pelanggan dipengaruhi oleh kondisi dan situasi internal dari UMKM yang diukur dengan ketersediaan sumberdaya manusia, baik secara kualitatif maupun kuantitatif, ketersediaan, modal yang cukup serta pengelolaan keuangan yang efektif dan efisien, ketersediaan sarana dan prasarana yang mendukung kegiatan usaha. Selain itu teknik pengolahan produk dan membuat produk yang memiliki keunikan, kualitas produk juga menjadi bagian penting dalam meningkatkan penjualan. Penentuan harga jual yang bersaing sesuai dengan daya beli konsumen juga perlu dipertimbangkan oleh para pengelola UMKM. Dan yang tidak kalah penting adalah lokasi usaha yang strategis, mudah dijangkau, serta nyaman menjadi faktor daya tarik bagi konsumen. Jika faktor internal tersebut telah kelola dengan baik oleh UMKM, maka akan menjadi kekuatan yang dapat dimanfaatkan untuk mempertahankan dan meningkatkan kegiatan usaha UMKM. Dengan demikian UMKM perlu memaksimalkan faktor internal tersebut, agar kegiatan usahanya terus tumbuh dan berkembang sehingga UMKM dapat mempertahankan usahanya ditengahtengah kondisi ekonomi yang tidak stabil, maupun ketatnya persaingan.

Hasil penelitian ini menunjukan, Faktor Ekstenal juga memiliki pengaruh dan hubungan positif, searah terhadap Kinerja UMKM. Dengan demikian, pertumbuhan usaha UMKM membutuhkan dukungan dari pihak-pihak eksternal. Faktor eksternal yang meliputi peranan pemerintah melalui kebijakan-kebijakan yang mendukung, mempermudah, serta memberikan fasilitas yang luas kepada UMKM menjadi peluang yang sangat besar bagi pertumbuhan UMKM. Kebijakan pinjaman lunak dengan bunga ringan, jangka waktu panjang akan memampu menambah modal usaha, sehingga UMKM memiliki modal kerja yang lebih besar, sehingga mampu menjual produk lebih banyak, dan dan memperoleh pendapatan yang meningkat, dan pada akhirnya labanya juga meningkat. Kemudahan dalam pengurusan perijinan usaha, tersedianya akses yang mendukung menjadi faktor yang membantu UMKM dapat meningkatkan 
pendapatan dan laba, sehingga usahanya dapat tumbuh dan berkembang. Selain itu berbagai program pelatihan, pendampingan yang dilakukan oleh beberapa instansi, isntitusi, serta pihak swasta memberikan menambahan wawasan, pengetahuan, dan peingkatan kompetensi dalam pengelolaan usahanya, mulai dari desain produk, pengelolaan keuangan, penyusunan laporan keuangan, pemasaran, peningkatan pengetahuan manajerial, dan lain-lain dapat membantu pelaku UMKM meningkatkan kualitas dalam pengelolaan usahanya, sehingga dapat berjalan lebih teratur, sistematis, dan terukur. Hal ini dapat meningkatkan motivasi pelaku UMKM dalam mengelola usahanya. Dengan demikian peluang-peluang dari faktor eksternal tersebut memiliki dampak terhadap pertumbuhan UMKM, dengan memanfaatkan peluang yang ada, maka UMKM dapat mengurangi adanya risiko atau ancaman, sperti persaingan, kekurangan modal, kualitas produk, pemasaran, dan juga kualitas SDM. Dengan berkurangnya risiko, dan pemanfaatan peluang dari faktor eksternal tersebut, maka akan dapat meningkatkan kinerja UMKM.

\section{KESIMPULAN DAN SARAN}

\subsection{Kesimpulan}

Berdasarkan hasil pengolahan dan analisis data dalam penelitian ini, dapat disimpulkan sebagai berikut : a. Faktor Internal secara parsial memiliki pengaruh terhadap Kinerja UMKM, dimana nilai $t_{\text {hitung }}>t_{\text {tabel }}(5,833>1,9679)$, sedangkan berdasarkan persamaan regresi menunjukkan bahwa Faktor Internal memiliki hubungan positif dan searah dengan kinerja UMKM, sebesar 0,673.

b. Faktor Eksternal secara parsial berpengaruh terhadap Kinerja UMKM, dimana nilai $t_{\text {hitung }}>\mathrm{t}_{\text {tabel }}(3,116>1,9679)$, sedangkan berdasarkan persamaan regresi menunjukkan bahwa Faktor Eksternal memiliki hubungan positif dan searah dengan kinerja UMKM, sebesar 0,308.

c. Hasil Uji hipotesis simultan menunjukkan nilai $F_{\text {hitung }} 17,956>$ Ftabel 3,16, sehingga secara bersama-sama Faktor Internal dan Faktor Eksternal berpengaruh terhadap Kinerja UMKM. Kemampuan varian dari kedua variabel bebas tersebut dapat menjelaskan varian dari variabel Kinerja UMKM sebesar nilai $\mathrm{R}$ Square yaitu 0,464 atau sebesar $46,4 \%$.

\subsection{Saran}

Adapun beberapa saran yang dapat disampaikan penulis sesuai dengan kepentingan adalah sebagai berikut :

a. Adanya pelatihan-pelatihan yang dilakukan secara terprogram dan periodik bagi pelaku UMKM pada setiap wilayah, dan dilakukan pengawasan serta pembinaan dan pendampingan secara sistematis dan terukur. 
b. Pemerintah dan pihak terkait dapat memberikan fasilitas kemudahan permodalan, baik persyaratan, biaya bunga, dan jangka waktu angsuran, serta pelatihan berkaitan dengan tatacara proses, persyaratan berkaitan dengan pengajuan pinjaman melalui lembaga perbangkan

c. UMKM lebih meningkatkan kreativitas dan inovasi, dengan mengikuti berbagai pelatihan dan pendidikan berkaitan dengan pengembangan UMKM, baik produk mapun manajemen dalam pengelolaan keuangan. Serta melakukan pencatatan yang benar dan rutin guna melakukan pengawasan dan evaluasi usahanya.

\section{DAFTAR PUSTAKA}

Anonim. Profil Bisnis: "Usaha Mikro, Kecil, dan Menengah (UMKM)". Jakarta (ID). Lembaga Pengembangan Perbankan Indonesia: Bank Indonesia, 2015

Abidin, Abdullah, "Pengembangan Usaha Mikro Kecil dan Menengah (UMKM) Sebagai Kekuatan Strategis Dalam Mempercepat Pembangunan Daerah “, 2013

Ade Resalawati, : "Pengaruh Perkembangan Usaha Kecil Menengah Terhadap Pertumbuhan Ekonomi Pada Sektor UMKM Indonesia “, Jurnal Ekonomi dan Bisnis, Vol 4, 2015

David, Fred R. "Strategic Management: Concepts and Cases ", Twelfth Edition, Pearson Prentice Hall, New Jersey, 2010
Dirlanudin. "Paradigma Baru Pengembangan Usaha Kecil." Jurnal Ilmiah Niagara 1, no. 2, 2017

Dwitya Aribawa " Pengaruh Literasi Keuangan Terhadap Kinerja Dan Keberlangsungan UMKM di Jawa Tengah “. Vol 20 No. 1, 2016

Endang Purwanti, "Pengaruh Karakteristik Wirausaha, Modal Usaha, Strategi Pemasaran Terhadap Perkembangan Umkm Di Desa Dayaan Dan Kalilondo Salatiga", Jurnal Among Makarti, Vol.5 No.9, Juli 2012.

Husein Umar. "Studi Kelayakan Bisnis edisis 3.", Jakarta: Gramedia Pustaka Utama, 2011

Ikatan Akuntan Indonesia. 2016. "Standar Akuntansi Keuangan Entitas Tanpa Akuntabilitas Publik", Jakarta: Ikatan Akuntan Indonesia, 2011

Jeaning. Peter., Graham Beaver , "The Performance and Competitive Advantege of Small Firms: A Management Persfective", International Small Business Journal, 2012

Kieso, Donald. E.. and Weygandt. Jerry. J (terjemahan Herman Wibowo). 2011. "Akuntansi Intermediate", Jakarta: Erlangga, 2011

Lesceviva, M, "Rural Entrepreneurship Success Determinant, Unpublished Working Papers, Faculty of Economics, Latvian University of Agriculture “, Eksjo, Latvian, 2014

Maupa , Haris. "Factor-Faktor Yang Menentukan Pertumbuhan Usaha Kecil Di Sulawesi Selatan" Disertasi Program Pascasarjana UNHAS, 2014.

Moh. Fakhtul Mujib "Analisis FaktorFaktor Yang Berpengaruh Secara Langsung dan Tidak Langsung Terhadap Kinerja Usaha Kecil \& Menengah (UMKM)", 2010 
Mukti Fajar, ND. "UMKM Di Indonesia Prespektif Hukum Ekonomi”, Yogyakarta, Pustaka Pelajar, 2016

Munisu, Musran, "Pengaruh Faktor-Faktor Eksternal dan Internal Terhadap Kinerja Usaha Mikro Kecil dan Menengah(UMK) di Sulawesi Selatan", Jurnal Manajemen dan Kewirausahaan 12, 33-41, 2010.

Pandji Anoraga, "Ekonomi Islam Kajian Makro dan Mikro", (Yogyakarta: PT. Dwi Chandra Wacana, 2010

Pearce, John A. dan Richard B. Robinson. "Strategic Management Formulation, Implementation, and Control ", Twelfth Edition, McGrawHill, New York, 2011

Prawirosentono. S “ Kebijakan Kinerja Karyawan”, Yogjakarta, BPFE, 2009

Samir, A \& Larso, D. "Indentifikasi Faktor Faktor yang Mempengaruhi Kinerja UMKM Catering di Kota Bandung", Jurnal Sekolah Bisnis dan Manajemen Institut Teknologi Bandung. Vol 10, 2011.

Subroto Rapih, "Analisis Pengaruh Kompetensi Sumber Daya Manusia, Modal Sosial Dan Modal Finansial Terhadap Kinerja Umkm Bidang Garmen Di Kabupaten Klaten" Tesis Pascasarjana, Universitas Sebelas Maret, Surakarta, 2015

Sugiyono, "Metode Penelitian Bisnis", Alfabeta, Bandung, 2013

Sulaeman, Suhendar, "Pengembangan Usaha Mikro Kecil dan Menengah dalam Menghadapi Pasar Regional dan Global " , Infokop 25, www.depkop.go.id, 2014

Temtime, Zelealem T., and J. Pansiri, "Small Business Critical Succes/Failure Factors in Developing Economies: Some Evidence From Bostwana", American Journal of Applied Sciences, 2014
Undang-Undang No. 20 tahun 2008 tentang "Usaha Mikro, Kecil, dan Menengah, Jakarta.

Wida Purwidianti Tri Septin Muji Rahayu, "Pengaruh Faktor Internal Dan Eksternal Terhadap Kinerja Usaha Industri Kecil Dan Menengah Di Purwokerto Utara", Jurnal KINERJA, Volume 19, No.1, 2015

Wilkinson, B. (2012), "Small, Micro, And Medium Enterprise Development; Expanding The Option For Debt And Equity Finance. Financial Sector Workshop,National Economic Development And Labour Council (NEDLAC)", Johanesburg, south Africa, Iris, April, 2012. 